\title{
Health Vulnerabilities and Resilience to Climate Change: An Update of International Progress
}

\author{
Mohd. Arifuzzaman', M. Mizanur Rahman², Md. Sultan-Ul-Islam³, Md. Nezam Uddin 4
}

\begin{abstract}
Despite being one of the most important societal challenges of the $21^{\text {st }}$ century, public engagement with climate change currently remains low worldwide. Mounting evidence from across the behavioral sciences has found that most people regard climate change as a non-urgent and psychologically distant risk-spatially, temporally, and socially-which has led to deferred public decision making about mitigation and adaptation responses. Climate change is increasing risks to human health and to the health systems that seek to protect the safety and well-being of populations. Health authorities require information about current associations between health outcomes and weather or climate, vulnerable populations, projections of future risks and adaptation opportunities in order to reduce exposures, empower individuals to take needed protective actions and build climate-resilient health systems. Health authorities from local to national levels badly seek this information by conducting climate change and health vulnerability and adaptation assessments. While assessments can provide valuable information to plan for climate change impacts, they are often not integrated into adaptation decision making, probably because the health sector is not involved in climate change policy-making processes at the national level. Significant barriers related to data accessibility, a limited number of climate and health models, uncertainty in climate projections, and a lack of funding and expertise, particularly in developing countries, challenge health authority efforts to conduct rigorous assessments and apply the findings. This paper reviews the evolution of climate change and health vulnerability and adaptation assessments, including guidance developed from such projects, and implementation of the findings to support health adaptation action. The findings derived from the study will support collaborative efforts to protect health from current and future climate change hazards. Health authorities may benefit from additional resources to ensure that evidence about climate change impacts on health could effectively be translated into needed actions to build health resilience.
\end{abstract}

\section{INTRODUCTION:}

In recent time climate change is viewed as one of the most significant global problems which affect directly or indirectly alter the structure of the environment. ${ }^{1}$ The world's climate has always been changing between hotter and cooler periods due to various factors. Although the basic science of climate change is now clear, the full range of effects due to human influenced climate change is still not fully understood. However, it is known that climate change in the next hundred years will be significant and by the year 2100 best estimates predict between a $1.8^{\circ} \mathrm{C}$ and $4{ }^{\circ} \mathrm{C}$ rise in average global temperature, although it could possibly be as high as $6.4^{\circ} \mathrm{C}$. Food production will be particularly sensitive to climate change, because crop yields depend directly on climatic conditions (temperature and rainfall patterns) and could lead to food yields being reduced by as much as a third in the tropics and subtropics. Meanwhile future tropical cyclones will become stronger, with faster wind speeds increasing the amount of damage they cause; floods will become more common due to changing rainfall patterns and glacier melt in

\section{Authors' information:}

'Mohd. Arifuzzaman, Research Fellow, Institute of Environmental Science, University of Rajshahi, Rajshahi-6205

${ }_{2}^{2}$ Professor Dr. M Mizanur Rahman, Department of Geography \& Environmental Studies, University of Rajshahi, Rajshahi.

${ }^{3}$ Dr. Md. Sultan-UI-Islam, Professor \& Chairman, Department of Geology Mining, University of Rajshahi, Rajshahi-6205

${ }^{4}$ Md. Nezam Uddin, PhD Fellow, Institute of Environmental Science, University of Rajshahi, Rajshahi-6205

Correspondence: Mohd.Arifuzzaman, Mobile: 01710966543 e-mail: shekh_arif@yahoo.com 
the summer; sea-level rise could inundate large areas of low lying countries; and the changing climate may indirectly cause misery by increasing the incidence of disease and conflict. Furthermore, biological diversity the source of enormous environmental, economic, and cultural value will be threatened by climate change. ${ }^{2}$

To mitigate the adverse consequence of climate change, people's preparedness is essential. However, people's perceptions of climate change and the way they respond depend on their knowledge. ${ }^{3,4}$ So understanding local community perceptions on impacts, causes, and responses to climate change is vital for promotion of community resilience towards climate change. Communities perception about how climate is changing ${ }^{5}$ and their contribution is useful in identifying adaptation strategies. Populations in developing countries are more exposed to climate change and they have low capacity to react to the related impacts. For example, recurrent changing climate in West Africa has led to decrease in rainfall since the late $70 \mathrm{~s} .{ }^{6-12}$ This resulted in a reduction of stream flow and wetlands leading to severe droughts. ${ }^{13,14}$ Yet, instead of being proactive, communities are not prepared to react to the effects of climate change in West Africa. ${ }^{15}$ Although the observation of global climate change has been largely based on meteorological data, there is paucity of information on how humans use local ecological knowledge to recognize and respond to such changes. ${ }^{16}$ Adger et al. ${ }^{17}$ suggest that local communities could interpret and construct climate change trends and local indicators within a cultural setting. The United Nations (UN) recognizes the significant role played by indigenous knowledge, cultures, and traditional practices in promoting sustainable development, equity, and management of the environment. ${ }^{18}$ They further argue that since culture is embedded in societal modes of production, consumption, lifestyles, and social organization, it should be recognized in understanding both mitigation and adaptation to climate change. Understanding and building upon perceptions, experiences, and IK on climate change can contribute towards strengthening the resilience of poor societies who are characterized by weak infrastructure \& economic well-being. ${ }^{19}$

The impacts of global warming and climate change for Bangladesh seems to be most critical as large part of the population is chronically exposed and vulnerable to a range of natural hazards. The effects of global warming have already been evidenced in climate variability, change and extremes. More adverse impacts are projected for the coming decades, particularly for low lying coastline and flood plain ecosystems which characterize Bangladesh. To understand how global warming and climate change will impact Bangladesh in future, influence its development aspirations and chart its roadmap for sustainable development, three considerations are critical. The location of Bangladesh is in a deltaic plain of a major river basin, making it susceptible to floods and cyclones. The country is extremely populated in a small area, and one of the most densely populated in the world. The country is still a low-income country, particularly the people living in the coastal belt and river basin live below subsistence level, making them already vulnerable. So there is an urgent needto assess vulnerability of people and assess their plan for adaptation. As this a broader study and encompasses vulnerability in terms health, agriculture, environment and so on, it is beyond the scope of the present study to present it comprehensively. The present study would, therefore, be a review of the studies to assess vulnerability \& adaptation (V\&A) measures as part of efforts by governments and experts to better understand and respond to climate change risks to health. It provides information on the type of guidance that has been developed for conducting V\&A studies and summarizes national and subnational assessments that have been conducted. The importance of this study lies in helping to build the evidence-base of climate change impacts on health. Recommendations are then provided about supporting future V\&As, establishing local climate change health risks, vulnerabilities and adaptation activities and applying the knowledge generated to protect the health of populations. The study intends to attain 
the following objectives:

1) Provide an idea about climate and climate change

2) Highlight the evidences of climate change

3) Assessing People's vulnerability or adaptive response or preparedness to the potential ill-effects climate change on human health, in the context of Bangladesh

\section{METHODS:}

To estimate the number of national V\&As that have been conducted expert knowledge and the database of the World Health Organization (WHO) were used. WHO sourced data consisted of the results from the 2015 WHO Climate and Health Country Survey reported through the WHO/United Nations Framework Convention on Climate Change (UNFCCC) Climate and Health Country Profiles, $^{20}$ the unpublished results of a WHO commissioned review of assessments, and different reports from the WHO Regional Offices available online. The WHO Climate and Health Country Survey collects global data on a suite of indicators measuring global progress on climate change and health every two years. These indicators include the number of countries that have conducted a V\&A survey.

An additional semi-structured search of the PubMed and PMC revealed 20 articles with discussion of climate change and health V\&As. Of these 20 articles, 2 werereviewed as abstract only, and 18 received a full-text review. The review results supported the WHO data. A review of the United States Agency for International Development (USAID) database revealed a further 3 V\&A studies that have been conducted-in Uganda, Senegal and Mozambiquewith the assistance of USAID's African and Latin American Resilience to Climate Change (ARCC) Program.

\section{LITERATURES REVIEWED:}

\section{Climate and Climate change:}

Climateis defined as the weather conditions prevailing in an area in general or over a long period, at least consecutive 30 years. Simply it is the "average weather" in a place. It includes patterns of temperature, precipitation (rain or snow), humidity, winds, cloudiness, sunshine throughout the year, averaged over a series of years. Climate change may refer to the change in average weather conditions or in the time variation of weather around long-term average conditions. It is measured by variation in temperature, humidity, atmospheric pressure, wind precipitation, atmospheric particulate matter count and other meteorological variables over a prolonged period of time.

Climate patterns play a key role in shaping natural ecosystems and their dependent human economies and cultures. But the climate that we have come to expect is not what it used to be, as the past is no longer a reliable forecast of the future. Once, all climate changes occurred naturally. However, we started to alter our climate and environment through changing agricultural and industrial practices during the Industrial Revolution. Before the Industrial Revolution, human activity emitted very few gasses into the environment, but now we are influencing the mixture of gases in the atmosphere by fossil fuel burning and deforestation. With dramatic effects, our atmosphere is rapidly changing, and that transition is occurring faster than any changes seen in the last 2,000 years.(http://www.epa. gov/globalwarming/emissions/index.html).

\section{Highlighting the evidences of climate change:}

The impact of climate change on the environment and human health is far reaching and thus influencing social changes in many aspects. The impact of climate change has seen in numerous aspects, for instance human health, ecosystem health and biodiversity, food production, economic growth, tourism, and water resources. ${ }^{21}$

As a result of climate change, the world is now experiencing warming effects from intensive use of fossil fuel with increasing atmospheric greenhouse gases. According to an IPCC 22 report, global surface temperatures have risen by an average of $0.13^{\circ} \mathrm{C}$ per decade since 1950 . At the 
same time, on the scale of potential GHG emissions, global average surface temperatures can be raised from $1.8^{\circ} \mathrm{C}$ to $4^{\circ} \mathrm{C}$ by the end of the topic of the $21^{\text {st }}$ century. In fact, the atmosphere in the next few decades will begin to warm. ${ }^{22}$

Climate change consists of an increase in atmospheric temperature, melting of glaciers with consequent rise in sea level, sinking islands, lack of fresh water with consequent rise in disease, increased diarrhoeal disease and endemic mortality, increased coastal water temperature associated with proliferation of Vibrio cholerae with eventual rise in cholera. ${ }^{23}$ Every nation in the world in one way or another contributes to climate change phenomena involving industrialisation, fossil fuel burning, deforestation and unlimited use of resources and energy contributing to GHG emissions. ${ }^{24}$

\section{Impact of Climate Change on Human Health}

\subsection{Climate Change \& Health:}

Accumulated scientific evidence suggests that climate variability and change pose serious risks to people living across the globe. ${ }^{25-27}$ Extraordinary improvements to global health made in recent decades are at risk of reversal due to the anticipated impacts of climate change. ${ }^{28}$ Countries lacking adaptive potential, vulnerable populations (e.g. indigenous peoples, people relying on agricultural livelihoods) and certain regions facing severe challenges, such as small island developing countries and the Arctic, are more vulnerable to its effects. ${ }^{29}$ Climate change challenges countries ' efforts to achieve key sustainable development goals (SDGs) under the 2030 Sustainable Development Agenda (e.g., SDG 1-No Poverty; SDG 2-End Hunger; SDG 3-Good Health and Well-being; and SDG 6-Clean Water and Health). ${ }^{30}$ For example, climate change could lead to 100 million more people living in extreme poverty.

Evidence-based information on current and potential future health risks, vulnerable populations, and effective adaptation options are needed to prepare individuals and communities for climate change health impacts. ${ }^{31}$ This includes identifying innovative adaptations for public health officials to understand and respond to more severe and possibly compounding effects of future climate change, such as tipping-point threats and shock events beyond the range of current experiences. ${ }^{32}$

Changes in climate and the associated environmental changes continue to be reported globally. ${ }^{33,34}$ Such changes have significant and wide-ranging effects, including direct and indirect health and well-being impacts. ${ }^{35,36}$ While the health impacts of climate change are projected to be felt globally, some communities have been recognized as being particularly vulnerable to health-related climate change. ${ }^{37-40}$ The health impacts of climate change are often localized and dependent on geographic location, biophysical factors, social and environmental relationships, cultural practices, and traditional knowledge. ${ }^{41}$ Local vulnerability assessments support efforts to prepare for and adapt to the current and future impacts of climate change on Inuit health. ${ }^{42}$

While many tools are available to direct human health vulnerability assessments to climate change, they all share a common first step: working with local communities and national stakeholders to define and explain the most significant climatesensitive health outcomes (i.e. climate-sensitive health outcomes and variability) for a population/ region in question. ${ }^{43-47}$ In order to direct health research and effectively inform the creation of public health adaptation strategies and initiatives, this phase is necessary to identify and recognize climate-sensitive health priorities at adult, household, community and regional scales. ${ }^{48,49}$

\subsection{Physical Effects}

Climate-sensitive diseases include heat-related diseases, water-borne diseases, vector-borne diseases, air pollution-related diseases, and extreme weather-related diseases such as floods, droughts, wind storms and fires. Endemic diseases such as malaria and cholera, meningococcal meningitis, dengue, leptospirosis, and rickettsial infections are common transmissible diseases that are prone to climate change. Water-borne diseases are mainly transmitted by flood-water 
and cause extreme contamination as rainwater floods the urban metropolis and contributes to major pollution of natural water supplies. These catastrophic events occurred in southern Malaysia from mid-December 2006 to late January 2007, where the flood affected nearly 200,000 people along with 16 deaths reported. ${ }^{50}$

Increased difficulties in accessing quality water sources, due to climate change, contribute to the disease burden that ultimately impede the freedom to live a long and healthy life. Because of erratic rainfall, water supply and quality will be hampered, which in turn will lead to warmer climate conditions favoring the multiplication of aquatic-borne pathogens, particularly cholera and vector-borne diseases, such as malaria and dengue. ${ }^{51,52}$ Worldwide warmer temperatures contribute to the breeding of mosquitoes that may carry malaria. ${ }^{53}$ Higher levels of contamination associated with warmer environments are experienced in the environment, leading to a higher risk of mortality from respiratory diseases. Climate change has caused about 5.5 million deaths of human lives in 2000, according to Rodo et al. ${ }^{54}$ Due to malnutrition, 2.8 million of them were passed; another 1.5 million were thanks to diarrhoea, and malaria affected another 1 million lives. However, another 200,000 were lost due to flooding and interestingly, nearly half of all was lost in the area of East and South Asia.

\subsection{Psychological Effects}

Physiological effects due to temperature on the human body are well known as extreme heat or cold conditions can affect many body functions. Researchers have found some negative emotional reactions in some individuals due to climate change. ${ }^{55}$ Medical practitioners have also experienced the increased number of patients with anxiety, depression. ${ }^{56}$

Wide-ranging research has found a strong relationship between climate change and stress. ${ }^{57}$ Furthermore, researchers also note that the psychologist's consensus has grown tremendously on the impact of environmental issues and their impact on their behavioral aspects. ${ }^{58-60}$
Nevertheless, the IPPC study ${ }^{22}$ found that human behavior and its relationship with the components of climate change were the least important. Nevertheless, evidence appears to emerge that people are generally concerned about environmental issues and their effect on their physiological dimension. ${ }^{61}$

Food is known as health's backbone. So if food production is hampered by climate change, it will ultimately have a negative impact on our nutrition and health. Gohari and associates ${ }^{62}$ assessed the impacts of climate change on crop production and water quality of four main crops (wheat, barley, rice and maize) in the Zayandeh-Rud River Basin in Iran. Multi-model ensemble simulations are used for the study period (2015-2044) to resolve uncertainties in climate change projections. As a result of climate change, monthly temperature will rise by 1.1 to $1.5^{\circ} \mathrm{C}$ on average. For different months of the year, monthly variations for precipitation may be positive or negative. However, with climate change, precipitation will decrease by $11 \%$ to $31 \%$ on an annual basis. While warming may shorten the growing period, crop production and water productivity of all crops are expected to decrease due to lower precipitation and higher water requirements at higher temperatures. Rice and maize are more vulnerable to climate change due to their high demand for irrigation water among the four crops studied. As a consequence, their continued development under climate change can be affected. Considering the locally high economic and food importance of these crops in central Iran, this result is particularly important. ${ }^{62}$

\section{Assessment of people's vulnerability:}

People's awareness about the effect of climate change on health as indirect measure of vulnerability:

The impact of climate change is generally perceived by people from western countries. The level of awareness on climate change issues in developed countries is appreciably high. For instance, only $1 \%$ of the English have not heard of either 'climate change', 'global warming' or the 
'greenhouse effect'. ${ }^{63,64}$ In addition, $92 \%$ of Americans are aware of global warming by $76 \%$ have already viewed climate change caused a serious problem in all aspects of human life. ${ }^{65}$ However, the context of perceived awareness on the issues like environment, controlling energy consumption and health related by the young segments takes a low priority by previous academic researchers. ${ }^{66-69}$

To reverse global climate change trend needs widespread support for policies and opportunities to reduce carbon emissions. Although advocating carbon neutrality is definitely in the best interests of the environment, hindering economic growth is not in the material interests of nations or individuals. ${ }^{70}$

The success of environmental education programs, like Al Gore's The Climate Campaign, testifies to a perception that increasing awareness can alter individual attitudes and encourages activism, but there is little real evidence that this is so. ${ }^{71}$ Although short-term habits frequently alter as a result of educational experiences, ${ }^{72}$ the resulting behavioral changes are usually short-lived. ${ }^{73}$

Located on an active delta, Bangladesh is characterized by a high level of instability in the atmosphere that presents high exposure to climate hazards and natural disasters. The country annually faces floods, riverbank and coastal erosion and is also susceptible to cyclones that form in the Bay of Bengal due to the country's funnel shaped coast. ${ }^{74}$ High incidence of poverty, particularly in the coastal belt, further perpetuates socioeconomic vulnerability of local communities and the country as a whole. ${ }^{75}$

Globally, both the severity and frequency of disasters have increased significantly, and there is increasing recognition of the link between climate change and extreme events. ${ }^{22}$ Managing the Risks of Extreme Events and Disasters to Advance Climate Change Adjustment). In their research, Sarker et al $^{76}$ mentions the increasing trend in temperature in Bangladesh over the past three decades, especially during the moonsoon season. The Fourth Assessment Report of the
Intergovernmental Panel on Climate Change (IPCC-AR4) states that Bangladesh is predicted to experience an increase in average daytime temperatures of $1.0{ }^{\circ} \mathrm{C}$ by 2030 and $1.4{ }^{\circ} \mathrm{C}$ by $2050^{77}$ indicating the effects of anthropogenic climate change.

Bangladesh's coastal districts are uniquely vulnerable to climate change due to their very low elevation, with some of the land at sea level, the topography of the deltaic area and the Bay of Bengal (which funnel up seawater) and also socio-economic and infrastructural factors that restrict the country's low, though increasing, capacity to address the effects of climate change. ${ }^{78}$ It is well documented that the coastal regions of southwest Bangladesh are already being affected by slow onset of climatic stresses such as rising temperatures, salinity intrusion into agricultural soil and groundwater, as well as an increase in the occurrence and intensity of sudden shocks such as floods, cyclones, storm surges and riverbank erosion as a result of climate change. ${ }^{79,80}$

\section{Climate Change and Health Vulnerability and Adaptation Assessments:}

Health authorities perform climate change and risk assessments and adaptation assessments on a local, regional or national scale to identify and interpret information needed to prepare health systems for climate change impacts. The participatory design of these studies requires a number of stakeholders to support efforts to plan for climate change. We have a similar set of goals and procedures, although the nature of individual studies can vary considerably. Key evaluation functions include: ${ }^{81}$

- Increase knowledge and understanding of existing correlations between weather/ climate and health outcomes, including the wellbeing of communities most vulnerable to these risks;

- Provide health and emergency management agencies, stakeholders and the public with information on the extent and trend of current and future climate variability and change-related health risks; and 
- Identifying opportunities to integrate climate change issues into current policies and programs aimed at managing weather and climate-related health threats and developing new strategies where possible to mitigate and reduce the severity of potential risks;

- Acting as a benchmark study to track future risk changes and based policies and programs;

- Collaborating with industries such as water \& sanitation to encourage programs aimed at improving the health of the population in a changing climate.

The ultimate objective of an evaluation is to support the implementation of adaptation and risk management measures which are effective in reducing current and future climate-related risks to human health and well-being, including among populations most vulnerable to impacts. In partnership with a wide range of stakeholders within and outside the health sector, V\&As create evidence-based adaptation plans or approaches for health authorities. ${ }^{81}$ Health National Adaptation Plans (HNAPs) and the Building Climate Resilient Health Systems Operational Framework (2015) are complementary tools designed by WHO to apply V\&A information to define strategic goals and plans to build health resilience to climate change. HNAPs may be included as sector-specific adaptation plans. ${ }^{82,83}$

\section{DISCUSSION \& CONCLUSION:}

Climate change and health vulnerability and adaptation assessments ( $\mathrm{V} \& \mathrm{As}$ ) are an important instrument and process to obtain information for understanding and addressing climate changerelated risks. ${ }^{84}$ They can also provide the knowledge needed to realize potentially large health co-benefits from well-designed adaptation and greenhouse gas mitigation measures.Over the past few decades, the global evidence base on climate change effects on health has expanded through the publication of reports from the Intergovernmental Panel on Climate Change (IPCC), ${ }^{85,86}$ global disease burden analysis from climate change, ${ }^{87}$ and related research. ${ }^{88-90}$
Direct and indirect health impacts associated with climate change are caused by rising temperatures, altered patterns of precipitation, and increasingly severe and recurrent extreme weather events. ${ }^{22,26,88}$ Direct health impacts are caused by hazards such as heat waves, droughts and hurricanes, and indirect impacts are caused by exposure to disease vectors and air and water pollution. Rising levels of carbon dioxide can also increased the nutrient value in staple crops, contributing to climate change. This could increase food insecurity among certain populations, especially in developing countries. ${ }^{91}$ A number of social factors can either intensify the health effects of climate change's environmental effects or help mitigate them by public health initiatives. There are gaps in knowledge about the effects of climate change on public health, food distribution, hunger, rural communities, indigenous groups and marginalized people.

With well-designed adaptation steps, many of the health impacts of climate variability \& change can be minimized or prevented. ${ }^{26,84}$ Health adaptation refers to "the process of planning, implementing, tracking and reviewing plans, policies and measures to reduce and take advantage of opportunities related to climate change. ${ }^{92}$ Public health officials have decades of experience with well-known, successful measures to mitigate many climatic and weather-related health threats such as air and water pollution, contaminated food, vector-borne diseases, ozone depletion, and extreme weather events (e.g. heatwaves, floods, droughts, wildfires, ice storms, hurricanes). ${ }^{93}$

Further understanding of the health and wellbeing risks posed by climate change and advice available to health authorities for vulnerability assessment has resulted in more local, regional and national studies. Assessments on climate change and vulnerability to health and adaptation provide valuable information to health authorities to enhance the resilience of individuals, communities and health systems to climate change impacts. They also contribute to development of the global evidence-base on climate change and health needed to inform 
adaptation and greenhouse gas mitigation measures in the future, ensuring that they benefit the well-being of populations.

Expanded initiatives through V\&As to continue to build this global evidence base and inform the creation of solutions to protect against that threats from climate hazards include further development of both quantitative and qualitative evaluation approaches, techniques and guidance documents. ${ }^{94}$ This would include, for example, prioritizing adaptation choices, using qualitative methods to evaluate the future. Improved skills development in environmental health and epidemiology, which requires knowledge and expertise to identify health threats in the context of environmental and climate change, will help health authorities in V\&As. More rigorous metrics and methods to quantify adaptive ability and the efficacy of existing adaptations, as well as more climate scenario and modeling knowledge specific to national and local scales, will boost the rigor of assessments. To order to prepare for potentially severe or catastrophic events, increased knowledge of systemic, synergistic, cascading or compounding health effects from climate change needs to be included in V\&As. Use V\&As as a key tool for fostering successful adaptation to climate change's health impacts would benefit from increased cooperation, communication and learning between health authorities.

\section{REFERENCES:}

1. United Nations Framework Convention on Climate Change, 1992; Costello et al., 2009.

2. Pender JS. 2014. What Is Climate Change? And How It May Affect Bangladesh. Cited: 7/8/2019, available at: http://www.greennewsbd.com/?p=307

3. Adger WN, Hug S, Brown K, Conway D, Hulme M. Adaptation to climate change in the developing world. Prog Dev Stud 2003;3(3):179-195. Doi: 10.1191/146 4993403ps060oa;

4. IFAD (International Fund for Agricultural Development) (2008) Climate change and the future of smallholder agriculture: How can rural poor people be part of the solution to climate change? Discussion Paper, Round Table on Climate Change at the Thirty-first Session of IFAD's Governing Council, Rome; Nyanga H, Johnsen $\mathrm{FH}$, Aune JB, Kalinda TH. Smallholder farmers' perceptions of climate change and conservation agriculture: evidence from Zambia. J Sustain u Develop 2011;4(4):73-85. Doi: 10.5539/jsd.v4n4p73.

5. Heijmans A, 2001. Vulnerability: a matter of perception. Disaster management Working Paper 4. University College of London.

6. Carbonnel JP, Hubert P. Pluviométrie en Afrique de l'Ouestsoudano-sahélienne : remise en cause de la stationnarité des séries. In : Le Floc'h E. (ed.), Grouzis Michel (ed.), Cornet Antoine (ed.), Bille Jean-Claude (ed.). L'aridité :unecontrainte au développement : caractérisation, réponsesbiologiques, stratégies des sociétés. Paris : ORSTOM, 1992:37-51. (Didactiques). ISBN 2-7099-1068-3

7. Nicholson SE, Some B, Koné B. An analysis of recent rainfall condition in West Africa, including the rainy seasons of the 1997 El Nino and the 1998 La Nina years. J Clim 2000;13:2623-2639.

8. Mahé G, L'Hôte $Y$, Olivry JC, Wotling G. Trends and discontinuities in regional rainfall of West and Central Africa (1951-1989). Hydrol Sci J 2001;46(2):211-226. Doi: $10.1080 / 02626660109492817$

9. Savane I, Coulibaly KM, Gioan P. Variabilitéclimatique et ressources en eauxsouterrainesdans la asin semi-montagneuse de Man. Sécheresse 2001;12(4): 231-237.

10. Tapsoba D, Bobbé B, Lebarbe L. Quelques caractéristiqu esévénementielles des régimes pluviométriques ponctuels Ouest africains au cours des deuxpériodes climatologiques contrastées (1951-1970 et19711991). Application de la loicomposéepoisson/ exponentielle (LCPE) ou du modèle de la loi des fuites (LDF) aux pluies. Sécheresse 2002;13(4):95-103.

11. Application de la loicomposéepoisson/exponentielle (LCPE) ou du modèle de la loi des fuites (LDF) aux pluies. Sécheresse 2002;13(4):95-103;

12. Kouakou KE, Goula BTA, Savane I. Impacts de la variabilitéclimatiquesur les ressources en eau de surface en zone tropicalehumide: cas du asin versant transfrontalier de la Comoé (Côte d'IvoireBurkina-Faso). Eur J Sci Res 2007;16(1):31-43.

13. Madiodio N, Abe A, Abou A (2004) Réduire la vulnérabilité de l'Afrique de l'Ouest aux impacts du climatsur les ressources en eau, les zones humideset la asin ification. UICN-Union mondiale pour la nature. Cited: 7/8/2019, available at: https://portals.iucn.org/ library/efiles/documents/Climate-impactsF-prelims.pdf

14. Kouakou KE, Goula BTA. Et Savané I. Impacts de la variabilitéclimatiquesur les ressources en eau de surface en zone tropicalehumide:cas du bassin 
transfrontalier de la Comoé (Côte d'Ivoire-Burkina Faso). European Journal of Scientific Research 2007; 16(1):31-43.

15. Climate Change Capacity Development $(\mathrm{C} 3 \mathrm{D}+)$ project, 2013. Guidebook for researchers and adaptation practitioners working with local communities. Adaptation toolkit. Anna Taylor, Stockholm Environment Institute (SEI), Oxford.

16. Savo V, Lepofsky D, Benner JP, Kohfeld KE, Bailey J, Lertzman K. Observations of climate change among subsistence-oriented communities around the world. Nature Climate Change 2016;6(5):462-473. Doi: 10.1038/nclimate2958.

17. Adger WN, Barnett J, Brown K, Marshall N, O'brien K. Cultural dimensions of climate change impacts and adaptation. Nature Climate Change 2013;3(2):112117. Doi: $10.1038 /$ nclimate 1666

18. United Nations. Sustainable Development Goals. San Francisco, CA, USA: United Nations; 015. https:// sustainabledevelopment.un.org/?menu $=1300$.

19. Codjoe SNA, Owusu G, Burkett V. Perception, experience, and indigenous knowledge of climate change and variability: the case of Accra, a sub-Saharan African city. Regional Environmental Change 2014;14(1):369-383.

20. World Health Organization (WHO) WHO UNFCCC Climate Health Country Profile Project-Monitoring Health Impacts of Climate Change and Progress in Building Climate Resilient Health Systems. Cited: 15/7/2018, 2018 Available at: http://www.who.int/ globalchange/ resources/countries/en/

21. Kovats RS, Campbell-Lendrum D, Matthies F. Climate change and human health: Estimating avoidable deaths and disease. Risk Analysis 2005;25(6):1409-1418.

22. IPCC Climate Change. Synthesis Report, Summary for Policymakers. 2007:14.

23. Halady RI, Rao HP. Does awareness to climate change lead to behavioral change? International Journal of Climate Change Strategies and Management 2009;2 (1):6-22..

24. ADB. Manila: Asian Development Bank; 2008. Climate Change, Programs Strengthening Mitigation and Adaptation in Asia and The Pacific.

25. World Health Organization (WHO) Quantitative Risk Assessment of the Effects of Climate Change on Selected Causes of Death, 2030s and 2050s. World Health Organization (WHO); Geneva, Switzerland: 2014.

26. Smith RK, Woodward A, Campbell-Lendrum D, Chadee DD, Honda Y, Liu Q, Olwoch JM et al., editors. Climate
Change 2014: Impacts, Adaptation, and Vulnerability. Part A: Global and Sectoral Aspects. Contribution of Working Group II to the Fifth Assessment Report of the Intergovernmental Panel on Climate Change. Cambridge University Press; Cambridge, UK: New York, NY, USA: 2014. pp. 709-754. Cited: 30/7/2018. Available at: http://www.ipcc.ch/pdf/assessment-report/ar5/wg2/ WGIIAR5-Chap11_FINAL.pdf,

27. Horton R, Beaglhole R, Bonita R, Raeburn J, McKee M, Wall S. From public to planetary health: A manifesto. Lancet 2014;282:9920. doi: 10.1016/S0140-6736(14) 60409-8.

28. Horton et al., 2014; Watts N, Adger WN, Agnolucci P, Blackstock J, Byass P, Cai W, Chaytor S, Colbourn T, Collins $M$, Cooper $A$, et al. Health and climate change: Policy responses to protect public health. Lancet 2015;386:1861-1914.doi:10.1016/S0140-6736(15) 60854-6.

29. Watts N, Amann M, Ayeb-Karlsson S, Belesova K, Bouley $\mathrm{T}$, Boykoff $\mathrm{M}$ et al. The Lancet Countdown on health and climate change: From 25 years of inaction to a global transformation for public health. Lancet 2018;391: 581-630.doi: 10.1016/S0140-6736 (17)32464-9.

30. United Nations Development Program (UNDP) Sustainable Development Goals. Cited: 15/7/2018; Available at: http://www.undp.org/content/undp/en/ home/sustainable-development-goals.html.

31. World Health Organization and Pan American Health Organization. World Health Organization; 2013. Cited: 15/7/2018. Protecting Health from Climate Change: Vulnerability and Adaptation Assessment. Available at: http://www.who.int/iris/handle/10665/104200; World Health Organization (WHO) World Health Organization; 2015. [(accessed on 15 July 2018)]. Operational Framework for Building Climate Resilient Health Systems. Available online: http://apps.who.int/ iris/bitstream/10665/189951/1/9789241565073_ eng.pdf?ua $=1$.

32. Ebi KL, Berry P, Boyer C, Hayes K, Enright PM, Sellers S, Hess JJ. Stress testing the capacity of health systems to manage climate change-related shocks and stresses. Int J Environ Res Public Health 2018;15:2370. doi: 10.3390/ijerph15112370.

33. Alley R, Berntsen T, Bindoff NL, Chen Z, Chidthaisong A, Friedlingstein P, et al. Climate Change 2007: The Physical Science Basis. Geneva, Switzerland: IPCC Secretariat; 2007. Füssel H-M. An updated assessment of the risks from climate change based on research published since the IPCC Fourth Assessment Report. Clim Change 2009;97:469-482. doi: 10.1007/s10584009-9648-5. 
34. IPCC. Intergovernmental Panel on Climate Change. 2013. Climate Change 2013: The Physical Science Basis.

35. Mc Michael AJ, Woodruff RE, Hales S. Climate change and human health: present and future risks. Lancet 2006;367:859-869. doi: 10.1016/S0140-6736(06) 68079-3;

36. Confalonieri U, Menne B, Akhtar R, Ebi KL, Hauengue M, Kovats RS, et al. Human Health. In: Parry ML, Canziani OF, Palutikof JP, Linden PJ V, et al., editors. Clim Chang 2007 Impacts, Adapt Vulnerability Contrib Work Gr II to Fourth Assess Rep Intergov Panel Clim Chang. Cambridge, UK: Hanson CE; 2007. pp. 391-431.

37. CunsoloWillox A, Harper SL, Ford JD, Landman K, Houle $\mathrm{K}$, Edge $\mathrm{VL}$, et al. From this place and of this place. climate change, sense of place, and health in Nunatsiavut, Canada. Soc Sci Med 2012;75:538-547. doi: 10.1016/j.socscimed.2012.03.043;

38. Harper SL, Edge VL, CunsoloWillox A, Rigolet Inuit Community Government "Changing climate, changing health, changing stories" profile: using an EcoHealth approach to explore impacts of climate change on Inuit health. Eco health 2012;9:89-101. doi: 10.1007/ s10393-012-0762-x.

39. CunsoloWillox A, Harper SL, Edge VL, Landman $K$, Houle $K$, Ford JD, et al. The land enriches the soul: On climatic and environmental change, affect, and emotional health and well-being in Rigolet, Nunatsiavut, Canada. Emot Sp Soc 2013;6:14-24.doi:10.1016/j.emospa. 2011.08.005.

40. Ford J, WilloxCunsolo A, Chatwood S, Furgal C, Harper S, Mauro I, Pearce T: Adapting to the effects of climate change on Inuit health. Am J Public Health 2014; 104(Suppl 3):e9-e17.

41. Ford JD. Indigenous health and climate change. Am J Public Health 2012;102:1260-1266. doi: 10.2105/ AJPH.2012.300752;

42. Ford et al., 2014; Ebi KL, Semenza JC. Communitybased adaptation to the health impacts of climate change. Am J Prev Med 2008;35:501-507. doi: 10. 1016/j.amepre.2008.08.018.

43. Ford JD, Smit B. A Framework for Assessing the Vulnerability of Communities in the Canadian Arctic to Risks Associated with Climate Change. Arctic 2004; 57:389-400. doi: 10.14430/arctic516;

44. Ebi KL, Kovats RS, Menne B. An Approach for Assessing Human Health Vulnerability and Public Health Interventions to Adapt to Climate Change. Environ Health Perspect 2006;114:1930-1934. doi:10.1289/ ehp.8880;
45. Frumkin H, Hess J, Luber G, Malilay J, McGeehin M. Climate change: the public health response. Am J Public Health 2008;98:435-445. doi: 10.2105/AJPH. 2007.119362;

46. Hess J, Malilay J, Parkinson A. Climate Change: The Importance of Place. Am J Prev Med 2008;35:468-478. doi: 10.1016/j.amepre.2008.08.024;

47. Hess JJ, McDowell JZ, Luber G. Integrating climate change adaptation into public health practice: using adaptive management to increase adaptive capacity and build resilience. Environ Health Perspect 2012; 120:171-179. doi: 10.1289/ehp.1103515.

48. Ford, 2012; Ford JD, Smit B. A Framework for Assessing the Vulnerability of Communities in the Canadian Arctic to Risks Associated with Climate Change. Arctic 2004;57:389-400. doi: 10.14430/arctic516.

49. Ford JD, Pearce T, Duerden F, Furgal C, Smit B. Climate change policy responses for Canada's Inuit population: The importance of and opportunities for adaptation. Glob Environ Chang 2010;20:177-191. doi: 10.1016/ j.gloenvcha.2009.10.008.

50. Tangang FT, Juneng L. Technical consultation report for National Hydraulic Research Institute of Malaysia (NAHRIM); 2011. Climate projection downscaling for Peninsular Malaysia and Sabah-Sarawak using Hadley Centre PRECIS model.

51. Shik lomanov IA. World water resources at the beginning of the 21st century. Paris: UNESCO Publications; 2001; Rodo X, Pascuar M, Fuchs G, Faruque $A$. ENSO and cholera: a nonstationary link related to climate change? Proceedings of the National Academy of Sciences of the USA. 2002;99(20) :12901-906.

52. Agrawala S, Tomoko O, Ahsan AU, Joel S, Maarten AV. Development And Climate Change In Bangladesh: Focus on Coastal Flooding and the Sundarbans. Organization for Economic Co-operation and Development. 2003.

53. Halady RI, Rao HP. Does awareness to climate change lead to behavioral change? International Journal of Climate Change Strategies and Management 2009; 2(1):6-22.

54. Rodo X, Pascuar M, Fuchs G, Faruque A. ENSO and cholera: a nonstationary link related to climate change? Proceedings of the National Academy of Sciences of the USA 2002;99(20):12901-906.

55. Fritze J. G, Blashki G. A, Burke S, Wiseman J. Hope, despair and transformation: climate change and the promotion of mental health \& wellbeing. International Journal of Mental Health Systems 2008;2(1):13. 
56. Miller N. Stressed by climate change? Go see your doctor. The Sydney Morning Herald 2008:3. first section: News and Features.

57. Swim J, Clayton S, Doherty T, Gifford R, Howard G, Reser J, Weber E. Washington, D.C: American Psychological Association; 2009. Psychology and global climate change: Addressing a multi-faceted phenomenon and set of challenges; Gifford R. Environmental psychology: Principles and practice. Fourth edition. Colville, WA: Optimal; 2007; azdin A. E. Psychological science's contributions to a sustainable environment. Extending our reach to a grand challenge of society. American Psychologist 2009;64:339-356. http://dx.doi.org/10.1037/a0015685.

58. Gardner GT, Stern PC. Environmental problems and human behaviour. Second Edition. Boston: Pearson Custom Publishing; 2002; Geller E. S. The challenge of increasing proenvironmentbehaviour. In: Bechtel RB, Churchman A, editors. Handbook of environmental psychology. New York: Wiley; 2002. pp. 525-540.

59. Gifford R. Environmental psychology: Principles and practice. Fourth edition. Colville, WA: Optimal; 2007; Oskamp S, Schultz P. W. Using psychological science to achieve sustainability. In: Donaldson S, Berger D, Pezdek K, editors. Applied psychology: New frontiers and rewarding careers. Mahwah, NJ: Lawrence Erlbaum; 2006. pp. 81-106.

60. Swim J, Clayton S, Doherty T, Gifford R, Howard G, Reser J, Weber E. Washington, D.C: American Psychological Association; 2009. Psychology and global climate change: Addressing a multi-faceted phenomenon and set of challenges; Vlek C, Steg L. Human behaviour and environmental sustainability. Journal of Social Issues 2007;63(Special issue):1-231. http://dx.doi.org/10.1111/j.1540-4560.2007. 00493.x.

61. Gow J, Leahy T. Apocalypse probably: agency and environmental risk in the hunter region. Journal of Sociology 2005;41:117-41.http://dx.doi.org/10.1177/ 1440783305050966.

62. Gohari A, Eslamian S, Abedi-Koupaei J, MassahBavani A, Wang D, Madani K. Climate change impacts on crop production in Iran's Zayandeh-Rud River Basin. Sci Total Environ 2013 Jan 1;442:405-19. doi: 10.1016/ j.scitotenv 2012.10.029. Epub 2012 Nov 23.

63. DEFRA. London: Department for Environment, Food and Rural Affairs; 2002. Survey of public attitudes to quality of life and to the environment 2001.

64. Lorenzonia Irene I, Nicholson-Coleb S, Whitmarsh L. Barriers perceived to engaging with climate change among the UK public and their policy implications. Global Environmental Change 2007;17:445-459.http:// dx.doi.org/10.1016/j.gloenvcha.2007.01.004.
65. Leiserowitz A. Global Warming in the American Mind: The Roles of Affect, Imagery, and Worldviews in Risk Perception, Policy Preferences and Behavior, Environmental Science, Studies and Policy, University of Oregon. 2003; PIPA. Data: Global Warming -Readiness to Accept Increases in Energy Costs. 2005. Retrieved from http://65.109.144.44/digest/ globalissues/ global warming/questionnaire $5 . \mathrm{cfm}$

66. Poortinga W, Pidgeon N, Lorenzoni I. Technical Report (No. Understanding Risk Working Paper 06-02) Norwich: Centre for Environmental Risk; 2006. Public perceptions of nuclear power, climate change and energy options in Britain: Summary findings of a survey conducted during October and November 2005.

67. DEFRA, 2002; Norton A, Leaman J. The Day After Tomorrow: Public Opinion on Climate Change. London: MORI Social Research Institute; 2004.

68. Poortinga W, Pidgeon N, Lorenzoni I. Technical Report (No. Understanding Risk Working Paper 06-02) Norwich: Centre for Environmental Risk; 2006. Public perceptions of nuclear power, climate change and energy options in Britain: Summary findings of a survey conducted during October and November 2005.

69. Leiserowitz A. Climate change risk perception and policy preferences: The role of affect, imagery, and values. Climatic Change 2006;77:45-72. http://dx.doi.org/10. 1007/s10584-006-9059-9.

70. Dyson T. On development, demography and climate change: the end of the world as we know it? Population and Environment 27:117-149; Woodward, D. 2008. Of "misguided" notions and misguiding nations: the growth report, poverty and climate change. Political Quarterly 2006;79:618-627.

71. Blumstein $D$, Saylan C. The failure of environmental education (and how to fix it). PLOS Biology 2008;5(5): e120 doi:10.1371/journal.pbio.0050120.

72. Kaiser F, Fuhrer U. 2003. Ecological behavior's dependency on different forms of knowledge. Applied Psychology: an International Review 52:598-613.

73. Dwyer WF, Leeming M, Cobern B, Porter-Jackson J. 1993. Critical review of behavioral intervention to preserve the environment. Environment and Behavior 25:274-321.

74. Mutahara M, Warner JF, Wals AEJ, Khan MSA, Wester P. Social learning for adaptive delta management: Tidal River Management in the Bangladesh Delta. International Journal of Water Resources Development 2017:1-21.

75. Hossain MA, Reza MI, Rahman S, Kayes I. Climate Change and its Impacts on the Livelihoods of the 
Vulnerable People in the Southwestern Coastal Zone in Bangladesh. Climate Change Management 2011; 237-259.

76. Sarker MAR, Alam K, Gow J. Exploring the relationship between climate change and rice yield in Bangladesh: An analysis of time series data. Agricultural Systems 2012;112:11-16.

77. Intergovernmental Panel on Climate Change [IPCC]. 2007. Chapter 10: Asia. In: Parry M, Canziani O, Palutikof J, van der Linden $\mathrm{P}$, Hanson C, editors. Climate change 2007: impacts, adaptation and vulnerability. Contribution of working group II to the fourth assessment report of the intergovernmental panel on climate change. Cambridge: Cambridge University Press; p. 469-506.

78. Agrawala S, Ota T, Ahmed AU, Smith J, Van Aalst M 2003. Development and climate change in Bangladesh: focus on coastal flooding and the Sundarbans (1-49). Paris: OECD

79. Rahman A, Alam M 2003. Mainstreaming adaptation to climate change in least developed countries (LDC). Working Paper 2: Bangladesh Country Case Study. International Institute for Environment and Development. London; Shamsuddoha M, \& Chowdhury RK 2007.

80. Climate change impact and disaster vulnerabilities in the coastal areas of Bangladesh. COAST Trust, Dhaka.; Haque I, Marschke M 2015. Climate change, Livelihood vulnerabilities and Social Protection in Bangladesh: Are social protection programs addressing livelihood vulnerabilities?. Unpublished manuscript, School of International Development and Global Studies, University of Ottawa.

81. World Health Organization and Pan American Health Organization. World Health Organization; 2013. Cited: $15 / 7 / 2018$. Protecting Health from Climate Change: Vulnerability and Adaptation Assessment. Available online: http://www.who.int/iris/handle/10665/104200.

82. World Health Organization. Geneva: 2014. Cited: 20/7/2018. WHO Guidance to Protect Health from Climate Change through Health Adaptation Planning. Available online: http://apps.who.int/iris/bitstream/ handle/10665/137383/9789241508001_eng.pdf?

83. United Nations Framework Convention on Climate Change (UNFCCC)/Least-developed Countries Expert Group (LEG) Geneva: 2012. Cited: 20/7/2018. The National Adaptation Plan Process. A Brief Overview. Available online: http://unfccc.int/files/adaptation/ application/pdf/19688_unfccc_nap_summary_low_v8. pdf.
84. Luber G, Lemery J, editors. Global Climate Change and Human Health: From Science to Practice.Jossey-Bass; San Francisco, CA, USA: 2015. Climate change and health vulnerability assessments.

85. Smith RK, Woodward A, Campbell-Lendrum D, Chadee DD, Honda Y, Liu Q et al., editors. Climate Change 2014: Impacts, Adaptation, and Vulnerability. Part A: Global and Sectoral Aspects. Contribution of Working Group II to the Fifth Assessment Report of the Intergovernmental Panel on Climate Change. Cambridge University Press; Cambridge, UK: New York, NY, USA: 2014. Cited: 30/7/2018. pp. 709-754. Available at: http://www.ipcc.ch/pdf/assessmentreport/ar5/wg2/WGIIAR5-Chap11_FINAL.pdf.

86. Confalonieri $U$, Menne $B$, Akhtar R, Ebi KL, Hauengue $M$, Kovats RS, Revich B, Woodward A, Abeku T, Alam M, et al. Human health. In: Parry ML, Canziani OF, Palutikof JP, van der Linden P.J., Hanson C.E., editors. Climate Change 2007: Impacts, Adaptation and Vulnerability. Contribution of Working Group II to the Fourth Assessment Report of the Intergovernmental Panel on Climate Change. Cambridge University Press; Cambridge, UK: 2007. Cited: 3/7/2018. Available at: www.ipcc.ch/ipccreports/ar4-wg2.htm.

87. World Health Organization (WHO) Quantitative Risk Assessment of the Effects of Climate Change on Selected Causes of Death, 2030s and 2050s. World Health Organization (WHO); Geneva, Switzerland: 2014. Campbell-Lendrum D., Woodruff R. Climate Change: Quantifying the Health Impact of Climate Change at National and Local Levels. World Health Organization; Geneva, Switzerland: 2007.

88. Watts N, Adger WN, Agnolucci P, Blackstock J, Byass $P$, Cai W, Chaytor S, Colbourn T, Collins M, Cooper A, et al. Health and climate change: Policy responses to protect public health. Lancet 2015;386:1861-1914. doi: 10.1016/S0140-6736(15)60854-6;

89. Watts N, Amann M, Ayeb-Karlsson S, Belesova K, Bouley T, Boykoff M, Byass P, Cai W, Campbell-Lendrum D., Chambers J., et al. The Lancet Countdown on health and climate change: From 25 years of inaction to a global transformation for public health. Lancet 2018;391:581-630.doi:10.1016/S0140-6736(17) 32464-9;

90. United States Global Change Research Program (USGCRP) In: The Impacts of Climate Change on Human Health in the United States: A Scientific Assessment.Crimmins A, Balbus J, Gamble JL, Beard $C B$, Bell JE, Dodgen D, Eisen RJ, Fann N, Hawkins MD, Herring SC, et al., editors. U.S. Global Change Research Program; Washington, DC, USA: 2016. 
91. Myers SS, Smith MR, Guth S, Golden CD, Vaitla B, Mueller ND, Dangour AD, Huybers P. Climate change and global food systems: Potential impacts on food security and undernutrition. Annu Rev Public Health 2017;38:259-277. doi: 10.1146/annurev- publhealth031816-044356.

92. Ebi K, Semenza JC. Community-based adaptation to the health impacts of climate change. Am J Prev Med 2008;35:501-507.doi:10.1016/j.amepre.2008. 08.018.
93. World Health Organization and Pan American Health Organization. World Health Organization; 2013. Cited: 15/7/2018. Protecting Health from Climate Change: Vulnerability and Adaptation Assessment. Available at: http://www.who.int/iris/handle/10665/104200;

94. Ebi $\mathrm{KL}$, Otmani del Barrio M. Lessons learned on health adaptation to climate variability and change: Experiences across low- \& middle-income countries. Environ. Health Perspect 2017;125:065001. doi:10. 1289/ EHP405. 